\title{
In Memoriam: Professor Dr Christian Schreiber
}

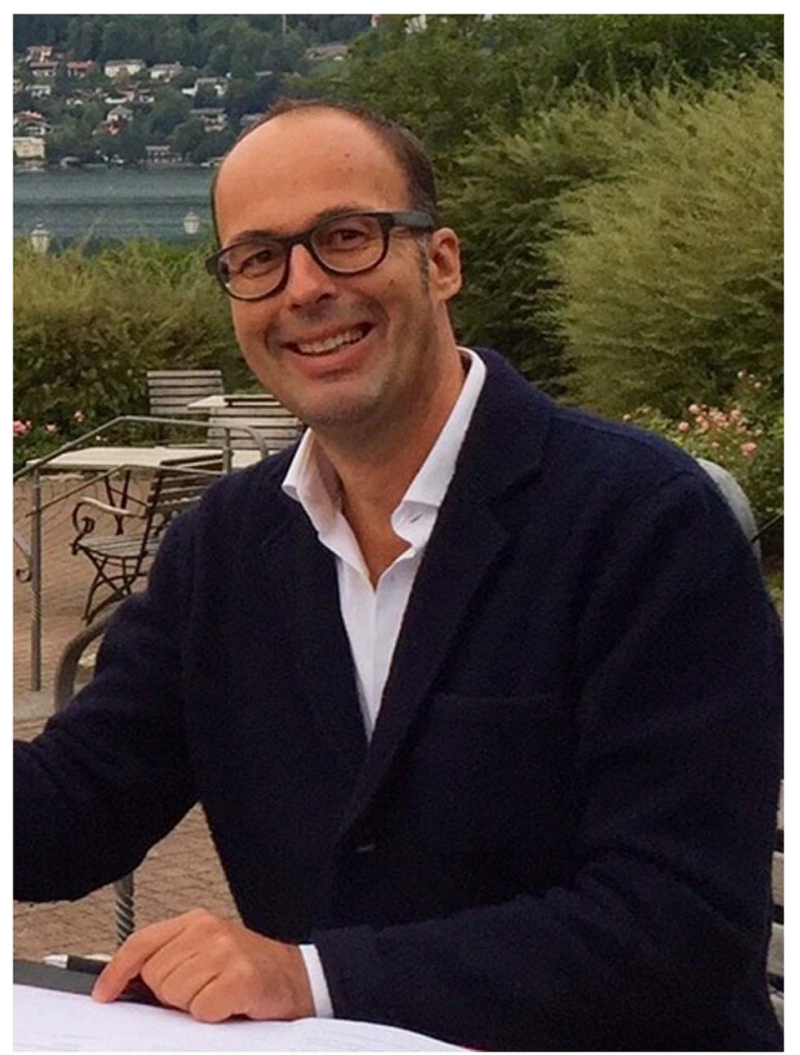

W

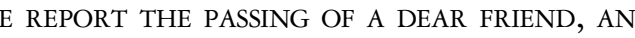
outstanding surgeon, a great scientist, and a wonderful teacher, Prof Dr Christian Schreiber from Munich, Germany. His family, all his friends, and colleagues are still in shock over his early death at the age of 50 years. Initially, without knowing the diagnosis of his insidious and deadly disease, amyotrophic lateral sclerosis (ALS), he continued to work in the operating theatre, although the initial symptoms made it progressively difficult for him to stand at the table. After he finally learnt the diagnosis, he fought the disease with all his strength and determination. He started a foundation "Face ALS" and devoted most of his time to this project. He connected with neurologists, immunologists, molecular biologists, and other ALS patients all over the world, with the same empathy and vigour, as he had done it in his specialty of paediatric cardiac surgery. Finally, he lost his battle against ALS after a horrible time of progressive weakness and immobilisation. For a man with exceptional energy and productivity, the last months of his life challenged his patience and faith in the future; however, despite his condition, he was always there for his colleagues, who contacted him for questions seeking help. We, as his most intimate friends, managed to visit him regularly and even took him out for dinner and excursions on occasions as long as he felt the slightest trace of vanishing power in his body. This was a time to speak about issues we had not been touching before and gave us an opportunity for a delayed farewell. On his death announcement, we quoted a citation from the Czech author Franz Kafka, which is more than pertinent to his last 3 years: "Man sieht die Sonne untergehen und erschrickt doch, wenn es plötzlich dunkel ist". "You see the sun go down and yet you are startled when it is suddenly dark".

After getting his medical license in 1991, Christian Schreiber worked as a medical doctor some time in Salvador de Bahia, Brazil. He became fluent in Portuguese and fell in love with this wonderful country, a very special love that he preserved until his death. After returning to Germany, he started his training under Prof Dr Fritz Sebening at the German Heart Center in Munich. He had always felt attracted by paediatric surgery, choosing paediatric cardiac surgery as the most challenging one. In 1998, he spent a year at the Great Ormond Street Hospital for Sick Children in London and performed studies on Ebstein's Morpholgy with Bob Anderson at the Royal Brompton. Bob became a dear friend later, I guess he was intrigued by Christian's intelligence, sense of humour, positive attitude, and surgical excellence.

Since 1999, Christian Schreiber and myself worked closely together. I observed a steep career of this young fellow. He passed his surgical boards in 2002 and got his $\mathrm{PhD}$ in 2006. At this time, he was already travelling extensively, performing paediatric cardiac operations in many parts of the world. Christian Schreiber received an Honorary Professorship from the Anzhen University Hospital in Peking, China, in 2006 and from the Linyi's Peoples Hospital in 
Shenyang, China, in 2008 for his surgical excellence and his extensive teaching efforts. At this time, Christian was just 41 and 43 years old, respectively. This was a great appreciation of his exceptional talent. In 2011, Christian Schreiber was appointed an Associate Professor at the Technical University of Munich, and the same year he became Deputy Director of the German Heart Center Munich, Germany.

Christian Schreiber was very busy in the Cardiothoracic Surgery Network. He was a member of the committee for New Technologies and of the Congenital Domain of the European Association of CardioThoracic Surgery. He was also an active member of the German Society for Thoracic and Cardiovascular Surgery and of the Working Group for Congenital and Paediatric Heart Surgery. He was a Co-Chair of the research committee of the World Society for Pediatric and Congenital Heart Surgery. Furthermore, he was a member of the Scientific Advisory Council of the "Heart to Heart" Foundation, Germany. Christian Schreiber was also Associate Editor for "Pediatric Cardiology", and was a member of the Editorial Board of the Brazilian Journal of Cardiovascular Surgery and of the German Thoracic Cardiovascular Surgeon.

Christian Schreiber was a passionate teacher at the Technical University Munich. He led numerous PhD students, gave lectures on paediatric cardiac surgery, and was enthusiastic to help surgeons in training to learn congenital heart surgery; two of his former disciples are now leading major programmes in large European centres.
No words can express our deep sadness about his passing. We miss a colleague who was never in a bad mood, who never yelled at anybody, who loved to joke, who carried us away with his endless energy. He was admired by anybody who worked with him. He was a superb surgeon and his surgical dexterity and talent and his control and calm in emergency situations made paediatric cardiac surgery look like the easiest thing in the world. He also conducted countless understanding and sensible talks with parents. After his death, hundreds of parents wrote in social media, "Thank you Prof Schreiber, thank you for saving our child's life!"

One of his unique talents was to connect colleagues and friends all over the world. He performed paediatric operations in so many countries that it is impossible for me to quote them all. He also made personal friendships with the local surgeons, and not only with the so-called "big names", but with every colleague who crossed his path. He loved people as much as he loved life.

We bow to a great surgeon and a beloved friend. It is terrible that YOU left us so early; however, we are relieved that your incredible suffering has come to an end.

Professor Dr. med. Ruediger Lange Deutschen Herzzentrum München Lazarettstraße 36,

DE 80636 München, Germany 